\title{
Hybrids within the genus Brassica and chemical mutants of Brassica napus - the potential sources of resistance to clubroot (Plasmodiophora brassicae)
}

\section{Formy mieszańcowe w obrębie rodzaju Brassica i mutanty chemiczne Brassica napus jako potencjalne źródła odporności na kiłę kapusty (Plasmodiophora brassicae)}

\author{
Janetta Niemann ${ }^{1}$, Joanna Kaczmarek ${ }^{2}$, Andrzej Wojciechowski ${ }^{1}$, \\ Jan Olejniczak², Małgorzata Jędryczka*
}

\section{Summary}

Clubroot, caused by a protozoan parasite Plasmodiophora brassicae Woronin, dwelling in the soil, is a serious threat not only to the health of cruciferous vegetables, but also to oilseed rape (Brassica napus L.). The aim of the study was to find potential sources of resistance to clubroot among hybrid forms within Brassica and chemical mutants of $B$. napus (MNU, 32 lines). The material consisted of interspecific hybrids of Brassica napus $\times$ B. juncea (F3-F5, 6 lines), B. napus $\times B$. carinata (F4-F6, 26 lines), B. napus $\times$ B. campestris ssp. pekinensis (F4-F6, 50 lines) and B. napus $\times$ B. campestris var. trilocularis (F4-F6, 50 lines). The maternal form used in experiments was a male sterile line of $B$. napus MS8, selected from resynthesized oilseed rape (B. rapa ssp. chinensis $\times$ B. oleracea var. gemmifera) using in vitro cultures of isolated embryos. The study was conducted using a bioassay with $P$. brassicae isolates belonging to the races P1-P5. The range of variation within the tested material differed from the range found in parental materials in eight out of ten cases. Forms with increased resistance to clubroot have been found among studied hybrids and mutants.

Key words: Brassica hybrids; clubroot; Plasmodiophora brassicae; chemical mutant; breeding for resistance

\section{Streszczenie}

Kiła kapusty, wywoływana przez pierwotniaka Plasmodiophora brassicae Woronin bytującego w glebie, stanowi silne zagrożenie dla zdrowotności roślin kapustowatych, w tym głównie warzyw kapustnych i rzepaku (Brassica napus L.). Celem badań było określenie odporności na kiłę kapusty u wybranych form mieszańcowych w obrębie Brassica i mutantów chemicznych B. napus (MNU, 32 linie). Materiał badawczy stanowiły mieszańce międzygatunkowe Brassica napus $\times$ B. juncea (pokolenia F3-F5, 6 linii), B. napus $\times$ B. carinata $(\mathrm{F} 4-\mathrm{F} 6,26$ linii), B. napus $\times$ B. campestris ssp. pekinensis $(\mathrm{F} 4-\mathrm{F} 6,50$ linii) oraz $B$. napus $\times$ B. campestris var. trilocularis (F4-F6, 50 linii). Jako formę mateczną stosowano męskosterylną linię $B$. napus MS8, wyselekcjonowaną z resyntetyzowanego rzepaku ozimego (B. rapa ssp. chinensis $\times$ B. oleracea var. gemmifera) z wykorzystaniem kultur in vitro izolowanych zarodków. Badania prowadzono za pomocą biotestu z wykorzystaniem izolatów $P$. brassicae należących do ras P1-P5. W ośmiu spośród dziesięciu przypadków, zakres zmienności w obrębie testowanego materiału różnił się istotnie od zakresu stwierdzanego u form rodzicielskich. Wśród uzyskanego potomstwa mieszańcowego i mutantów stwierdzono występowanie form o podwyższonej odporności na kiłę kapusty.

Słowa kluczowe: formy mieszańcowe Brassica; kiła kapusty; Plasmodiophora brassicae; mutant chemiczny; hodowla odpornościowa

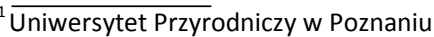
Katedra Genetyki i Hodowli Roślin Dojazd 11, 60-632 Poznań

${ }^{2}$ Instytut Genetyki Roślin Polskiej Akademii Nauk

Strzeszyńska 34, 60-479 Poznań

*corresponding author: mjed@igr.poznan.pl
} 


\section{Wstęp / Introduction}

Kiła kapusty, wywoływana przez patogeniczne pierwotniaki Plasmodiophora brassicae Woronin bytujące w glebie, uważana jest za jedną z najgroźniejszych chorób rzepaku i innych roślin $\mathrm{z}$ rodziny Brassicaceae. W Polsce już od wielu lat objawy wywoływane przez tego patogena obserwowano na roślinach warzywnych (Robak 1991). W ostatnich latach, zarówno w naszym kraju, jak też w wielu innych krajach Europy i w Kanadzie, obserwuje się pandemiczne narastanie porażenia roślin rzepaku przez P. brassicae (Robak 1991; Lüders i wsp. 2011; Jędryczka i wsp. 2012; Korbas i Jajor 2013). Choroba stanowi istotne zagrożenie i może powodować duże straty plonu (Pageau i wsp. 2006; Jajor i wsp. 2009). W wyniku porażenia, $\mathrm{z}$ powodu deformacji systemu korzeniowego zakłócone zostają procesy fizjologiczne roślin (Agrios 2005; Rimmer i wsp. 2007; Jajor i wsp. 2008).

Ze względu na monokulturowy charakter uprawy roślin kapustowatych i nieprzestrzeganie podstawowych zasad zmianowania istnieje możliwość dalszego rozszerzania zasięgu występowania tej choroby. Informacje te są bardzo niepokojące $\mathrm{z}$ uwagi na wyjątkową żywotność zarodników przetrwalnikowych, które mogą bytować w glebie przez okres 20 lat, zachowując swoją infekcyjność (Dixon 2009), co stanowi istotny problem w ograniczaniu szkodliwości kiły kapusty na rzepaku metodami chemicznymi i agrotechnicznymi. Za podstawową i jednocześnie najbardziej skuteczną metodę zapobiegania występowaniu kiły uważa się uprawę odmian odpornych (Rahman i wsp. 2011). Hodowla odpornościowa już od ponad 50 lat była na świecie istotnym celem badań prowadzonych przez hodowców warzyw rodzaju Brassica (Wallenhammar 1996). Pojawienie się objawów kiły kapusty na uprawach w Europie, przyspieszyło rozwój badań nad genetyczną odpornością rzepaku na tę chorobę (Diederichsen i wsp. 1996; Rahman i wsp. 2011). Dużym utrudnieniem dla naukowców jest jednak ograniczona liczba źródeł odporności. Ocenia się, że największe prawdopodobieństwo ich znalezienia istnieje w geograficznych centrach pochodzenia danych gatunków (Kopecky i wsp. 2012). Ze względu na to, że wiele form należących głównie do gatunków: $B$. campestris i $B$. oleracea oraz Raphanus sativus L. zawiera geny odporności na kiłę kapusty (Diederichsen i wsp. 1996; Nomura i wsp. 2005; Kamei i wsp. 2010), możliwa jest ich introdukcja do rzepaku przez krzyżowanie oddalone. Pierwsze odporne na kiłę odmiany rzepaku ozimego (Mendel i Tosca) uzyskane w wyniku krzyżowania wyprowadzili hodowcy europejscy (Diederichsen i wsp. 2009). Odmiany te zostały wprowadzone na rynek w latach 90 . XX wieku. W wyniku badań nad populacjami $P$. brassicae wyodrębnionymi z rzepaku hodowanego w różnych lokalizacjach we Francji, stwierdzono znaczny polimorfizm genetyczny (Manzanares-Dauleux i wsp. 2001). Wykazano także, że genetyczna odporność na tego patogena może dotyczyć określonej rasy, bądź szerokiego spektrum patotypów (Diederichsen i wsp. 1996). W programach hodowlanych dotyczących wprowadzania genów odporności, niezmiernie ważne jest uwzględnienie ściśle zdefiniowanych patotypów, rozpowszechnionych w danym rejonie geograficznym.
Celem badań było określenie czy formy mieszańcowe w obrębie Brassica i mutanty chemiczne B. napus uzyskane przy wykorzystaniu N-nitroso-N-metylomocznika (MNU) mogą stanowić potencjalne źródła odporności na kiłę kapusty.

\section{Materiały i metody / Materials and methods}

Materiał badawczy stanowiły mieszańce międzygatunkowe Brassica napus $\times$ B. juncea (pokolenia F3-F5, 6 linii), B. napus $\times$ B. carinata (F4-F6, 26 linii), B. napus $\times$ B. campestris ssp. pekinensis (F4-F6, 50 linii) oraz B. napus $\times$ B. campestris var. trilocularis (F4-F6, 50 linii). Jako formę mateczną stosowano męskosterylną linię rzepaku ozimego MS8, wyselekcjonowaną z resyntetyzowanego rzepaku ozimego (B. campestris ssp. chinensis $\times$ B. oleracea var. gemmifera) $\mathrm{z}$ wykorzystaniem kultur in vitro izolowanych zarodków (Wojciechowski 1993). Ponadto badania wykonano na nasionach zebranych $\mathrm{z}$ form B. napus poddanych działaniu MNU, zebranych $\mathrm{z}$ roślin pokolenia F5.

Izolaty należące do poszczególnych ras rozmnożono z fragmentów wyrośli na korzeniach rzepaku, dwukrotnie pasażowanych na formie $B$. campestris podatnej na kiłę kapusty. Testowanie prowadzono oddzielnie dla ras P1-P5. Przynależność do patotypów określono według systemu zaproponowanego przez Somé i wsp. (1996).

Podatność roślin na kiłę kapusty określono na podstawie biotestu, porównując reakcję analizowanych roślin $\mathrm{z}$ wynikami uzyskanymi dla podatnego genotypu $B$. campestris ssp. pekinensis. Jako drugi wzorzec zastosowano odmianę rzepaku ozimego Mendel F1 (NPZ-Lembke) z genami odporności na kiłę.

Nasiona badanych genotypów wysiewano do mieszaniny gleby z kwaśnym torfem o pH 3,5 w proporcji: 2 części badanej gleby i 1 część kwaśnego torfu po 5 nasion do 4 doniczek w doniczkopalecie, w dwóch powtórzeniach. Wzrost roślin odbywał się w szklarni z zapewnieniem warunków stałego dostępu światła (doświetlanie przez 14 godzin) i temperaturze powietrza $22-24^{\circ} \mathrm{C}$.

Inokulacje wykonywano przez nanoszenie pod każdą kiełkującą siewkę $2 \mathrm{ml}$ zawiesiny zarodników o stężeniu $2,5 \times 10^{6} \mathrm{spor} / \mathrm{ml}$. Ocenę odporności roślin przeprowadzano po upływie 6 tygodni od inokulacji. Oceniano zdrowotność systemu korzeniowego i ogólną kondycję roślin, przy użyciu pięciostopniowej skali, gdzie 0 - oznaczało brak objawów choroby, a 4 - obecność dużych wyrośli na korzeniach inokulowanych roślin. W celu wykonania obserwacji wszystkie rośliny wyjmowano z podłoża, a korzenie płukano w wodzie dla łatwiejszego wykonania obserwacji.

Wnioskowanie dotyczące istotności różnic między obiektami badawczymi prowadzono na podstawie jednoczynnikowej analizy wariancji. W przypadku, gdy analiza wariancji nie wykazała istotności różnic między rozpatrywanymi grupami, nie przeprowadzano kolejnych testów. Natomiast, gdy hipoteza zerowa została odrzucona, tzn. na podstawie analizy wariancji stwierdzono statystycznie istotne różnice pomiędzy obiektami badawczymi, badanie różnic między średnimi $\mathrm{z}$ poszczególnych grup przepro- 
wadzono testem Tukeya. Wszystkie wykazane różnice i wyznaczone współczynniki korelacji przyjęto za statystycznie istotne, $w$ przypadku poziomu istotności $\alpha \leq 0,05$. Obliczenia wykonano stosując pakiet statystyczny STATISTICA v. 9.0.

\section{Wyniki i dyskusja / Results and discussion}

Grupa roślin potomnych pochodzących z krzyżowania między formami rodzicielskimi oraz formy uzyskane na drodze mutacji chemicznych, wykazywały odmienny zakres zmienności cechy odporności na porażenie przez $P$. brassicae między sobą oraz $\mathrm{w}$ porównaniu do form rodzicielskich (rys. 1, tab. 1). Wyjątkiem od tej reguły były jedynie wyniki uzyskane dla mutantów chemicznych B. napus, po zastosowaniu inokulacji rasą P1 (rys. 1a) oraz wyniki uzyskane dla form mieszańcowych w obrębie Brassica inokulowanych rasą P2 (rys. 1b). W obu przypadkach zakres zmienności roślin rodzicielskich pokrywał się z zakresem zmienności ich potomstwa i nie stwierdzono statystycznie istotnych różnic między badanymi grupami
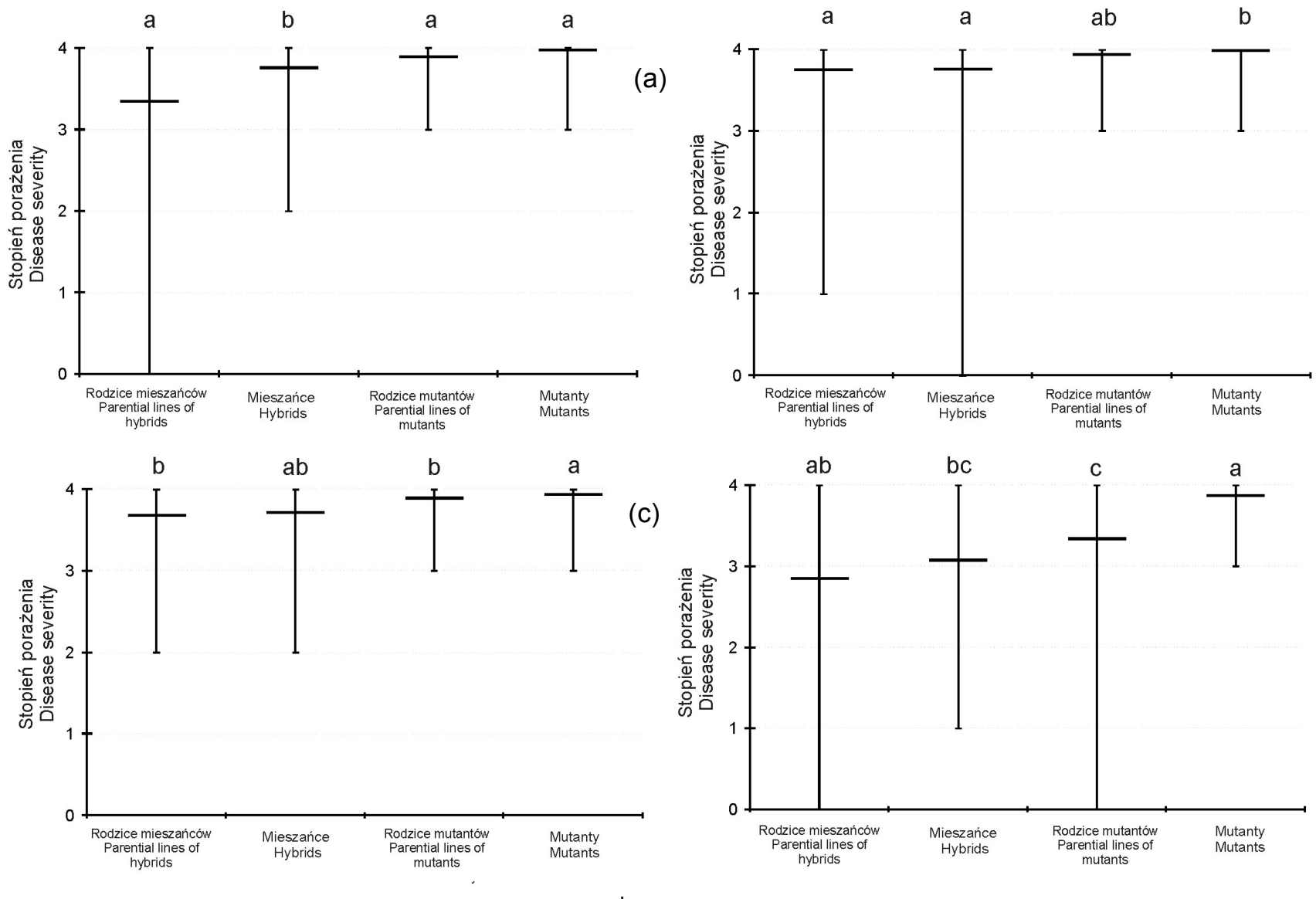

(d)

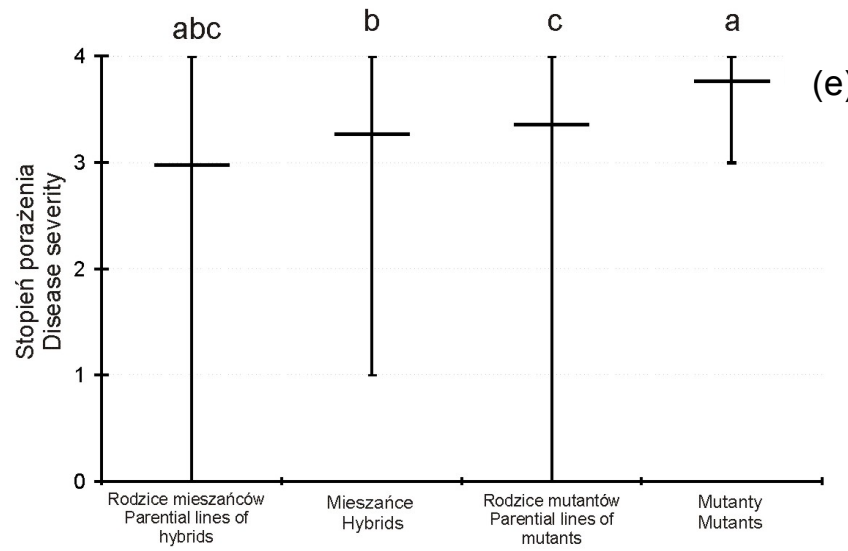

Wartości oznaczone różnymi literami różnią się istotnie $(p=0,05)$

Values followed by different letters are significantly different $(p=0.05)$

Rys. 1. Zakres zróżnicowania stopnia porażenia mieszańców międzygatunkowych w obrębie rodzaju Brassica oraz mutantów chemicznych (MNU) B. napus po inokulacji pierwotniakiem P. brassicae rasa P1 (a), rasa P2 (b), rasa P3 (c), rasa P4 (d), rasa P5 (e)

Fig. 1. Range of disease severity of interspecific hybrids within the genus Brassica and chemical mutants (MNU) of B. napus inoculated with a protozoan pathogen P. brassicae race P1 (a), race P2 (b), race P3 (c), race P4 (d), race P5 (e) 
Tabela 1. Zróżnicowanie odporności form mieszańcowych i mutantów chemicznych rodzaju Brassica na porażenie chorobotwórczym pierwotniakiem $P$. brassicae

Table 1. Differences in resistance of hybrids and chemical mutants within the genus Brassica to the infection with the protozoan pathogen P. brassicae

\begin{tabular}{|c|c|c|c|c|c|c|c|c|c|c|}
\hline \multirow{2}{*}{$\begin{array}{l}\text { Materiał roślinny } \\
\text { Plant material }\end{array}$} & \multicolumn{2}{|c|}{$\begin{array}{l}\text { Rasa P1 } \\
\text { Race P1 }\end{array}$} & \multicolumn{2}{|c|}{$\begin{array}{l}\text { Rasa P2 } \\
\text { Race P2 }\end{array}$} & \multicolumn{2}{|c|}{$\begin{array}{l}\text { Rasa P3 } \\
\text { Race P3 }\end{array}$} & \multicolumn{2}{|c|}{$\begin{array}{l}\text { Rasa P4 } \\
\text { Race P4 }\end{array}$} & \multicolumn{2}{|c|}{$\begin{array}{l}\text { Rasa P5 } \\
\text { Race P5 }\end{array}$} \\
\hline & $\begin{array}{l}\text { NIR } \\
\text { LSD }\end{array}$ & $\begin{array}{l}\text { zakres } \\
\text { range }\end{array}$ & $\begin{array}{l}\text { NIR } \\
\text { LSD }\end{array}$ & $\begin{array}{l}\text { zakres } \\
\text { range }\end{array}$ & $\begin{array}{l}\text { NIR } \\
\text { LSD }\end{array}$ & $\begin{array}{l}\text { zakres } \\
\text { range }\end{array}$ & $\begin{array}{l}\text { NIR } \\
\text { LSD }\end{array}$ & $\begin{array}{l}\text { zakres } \\
\text { range }\end{array}$ & $\begin{array}{l}\text { NIR } \\
\text { LSD }\end{array}$ & $\begin{array}{l}\text { zakres } \\
\text { range }\end{array}$ \\
\hline $\begin{array}{l}\text { Formy } \\
\text { mieszańcowe } \\
\text { Hybrids }\end{array}$ & 0,83 & $2,52-4,17$ & 0,61 & $3,15-4,47$ & 0,61 & $3,15-4,37$ & 1,17 & $2,17-4,51$ & 0,72 & $2,63-4,10$ \\
\hline $\begin{array}{l}\text { Mutanty } \\
\text { Mutants }\end{array}$ & 0,19 & $3,79-4,17$ & 0,10 & $3,89-4,08$ & 0,10 & $3,84-4,03$ & 1,14 & $1,71-3,98$ & 0,94 & $2,03-3,92$ \\
\hline
\end{tabular}

NIR - Najmniejsza Istotna Różnica

LSD - Lowest Significant Difference

obiektów. W przypadku rasy P1 średnia wartość porażenia form rodzicielskich przez $P$. brassicae wynosiła 3,76, natomiast dla grupy uzyskanych $\mathrm{z}$ nich roślin mieszańcowych była o 0,41 niższa; obie grupy różniły się statystycznie istotnie (rys. 1a). Objawy na formach $B$. napus poddanych działaniu MNU i inokulowanych rasą P2 wynosiły 3,99, natomiast wartość tego parametru dla form rodzicielskich wynosiła 3,94, czyli w tym przypadku nie uzyskano poprawy odporności na porażenie przez P. brassicae. Podobna sytuacja wystąpiła po inokulacji rasą P3, zastosowaną wobec form poddanych działaniu mutagenów; także i w tym przypadku potomstwo roślin traktowanych MNU było porównywalnie lub silniej porażone, niż formy rodzicielskie (rys. 1c). Odmienna sytuacja nastąpiła w przypadku poddania zmutowanych form działaniu ras P4 oraz $\mathrm{P} 5$. W obu przypadkach stwierdzono statystycznie istotne różnice między odpornością roślin rodzicielskich a odpornością form powstałych w wyniku działania mutagenu i była to różnica na korzyść uzyskanego potomstwa (rys. 1d, e). W reakcji na inokulację rasą $\mathrm{P} 4$ różnica ta wynosiła 1,03 , a po inokulacji rasą $\mathrm{P} 5$ różnica ta była nieco niższa i wynosiła 0,79 .

W przypadku roślin mieszańcowych statystycznie istotną różnicę na korzyść potomstwa obserwowano wyłącznie po inokulacji rasą P1 (rys. 1a). Średnie porażenie roślin mieszańcowych przez wszystkie rasy $P$. brassicae wyno- siło 3,52 i niewiele różniło się od średniego stopnia porażenia form rodzicielskich, wynoszącego 3,55, niemniej była to różnica na korzyść populacji roślin potomnych. Podobne spostrzeżenia poczynili Rahman i wsp. (2011), którzy testowali odporność na rasy 3 i 5 P. brassicae u linii mieszańcowych i form rodzicielskich. Badane przez nich linie wykazały zbliżony poziom odporności na testowane patotypy. Średnie porażenie form poddanych działaniu mutagenów w wyniku inokulacji z zastosowaniem wszystkich badanych ras $P$. brassicae było wyższe u form rodzicielskich $(3,88)$ niż $u$ form potomnych $(3,55)$, co świadczy o uzyskaniu potomstwa charakteryzującego się wyższą odpornością na porażenie przez $P$. brassicae.

\section{Wnioski / Conclusions}

Mieszańcowe rośliny w obrębie rodzaju Brassica i mutanty chemiczne $B$. napus mogą stanowić potencjalne źródła odporności na kiłę kapusty ( $P$. brassicae) lecz formy cechujące się odpornością są nieliczne.

Badania sfinansowano z projektu Narodowego Centrum Nauki N N310 298439.

\section{Literatura / References}

Agrios G.N. 2005. Plant Pathology. 5th ed. Elsevier Academic Press, San Diego, USA, 922 pp.

Diederichsen E., Wagenblatt B., Schallehn V., Deppe U., Sacristan M.D. 1996. Transfer to clubroot resistance from resynthesized Brassica napus into oilseed rape - identification of race-specific interactions with Plasmodiophora brassicae. In: Proceedings of the International Symposium on Brassicas. Acta Horticulturae 407: 423-429.

Diederichsen E., Frauen M., Linders E.G.A., Hatakeyama K., Hirai M. 2009. Status and perspectives of clubroot resistance breeding in crucifer crops. Journal of Plant Growth Regulation 28: 265-281.

Dixon G.R. 2009. The occurrence and economic impact of Plasmodiophora brassicae and clubroot disease. Journal of Plant Growth Regulation 28: 194-202.

Jajor E., Korbas M., Kozłowski J., Mrówczyński M., Pruszyński G., Wachowiak H., Walczak F., Węgorek P. 2008. Poradnik sygnalizatora ochrony rzepaku. Instytut Ochrony Roślin - Państwowy Instytut Badawczy, Poznań, 153 ss.

Jajor E., Korbas M., Budka A. 2009. Ograniczanie kiły kapusty (Plasmodiophora brassicae) w rzepaku ozimym przy użyciu tiofanatu metylu. [Reduction of clubroot (Plasmodiophora brassicae) on winter oilseed rape using methyl tiophanate]. Progress in Plant Protection/Postępy w Ochronie Roślin 49 (3): 1268-1272. 
Jędryczka M., Korbas M., Jajor E., Danielewicz J., Kaczmarek J. 2012. Występowanie Plasmodiophora brassicae w glebach z uprawami roślin rolniczych w Wielkopolsce, w latach 2011-2012. [The occurrence of Plasmodiophora brassicae in agricultural soils in Wielkopolska region, in 2011-2012]. Progress in Plant Protection/Postępy w Ochronie Roślin 53 (4): 774-778.

Kamei A., Tsuro M., Kubo N., Hayashi T., Wang N., Fujimura T., Hirai M. 2010. QTL mapping of clubroot resistance in radish (Raphanus sativus L.). Theoretical and Applied Genetics 120: 1021-1027.

Kopecky P., Dolezalowa I., Duchoslav M., Dusek K. 2012. Variability in resistance to clubroot in european cauliflower cultivars. Plant Protection Science 48 (4): 146-161.

Korbas M., Jajor E. 2013. Kiła kapusty - narastający problem w uprawie rzepaku. Materiały informacyjne. Instytut Ochrony Roślin Państwowy Instytut Badawczy, Poznań, Syngenta, Warszawa, 15 ss.

Lüders W., Abel S., Friedt W., Kopahnke D., Ordon F. 2011. Auftreten von Plasmodiophora brassicae als Erreger der Kohlhernie im Winterrapsanbau in Europa sowie Identifizierung, Charakterisierung und molekulare Kartierung neuer Kohlhernieresistenzgene aus genetischen Ressourcen Drittes Nachwuchswissenschaftlerforum. Quedlinburg, 23-25 November 2010. Julius-Kuhn-Archiv 430: 40-43.

Manzanares-Dauleux M.J., Divaret I., Baron F., Thomas G. 2001. Assessment of biological and molecular variability between and within field isolates of Plasmodiophora brassicae. Plant Pathology 50: 165-173.

Nomura K., Minegishi Y., Kimizuka-Takagi C., Fujioka T., Moriguchi K., Shishido R., Ikehashi H. 2005. Evaluation of F2 and F3 plants introgressed with QTL's for clubroot resistance in cabbage developed by using SCAR markers. Plant Breeding 124: 371-375.

Pageau D., Lajeunesse J., Lafond J. 2006. Impact de l'hernie des crucife'res (Plasmodiophora brassicae) sur la productivite`et la qualite du canola. Canadian Journal of Plant Pathology 28: 137-143.

Rahman H., Shaker A., Hasan M.J. 2011. Breeding for clubroot resistant spring canola (Brassica napus L.) for the Canadian prairies: Can the European winter canola cv. Mendel be used as a source of resistance? Canadian Journal of Plant Science 91 (3): $447-458$

Rimmer S.R., Shattuck V.I., Buchwaldt I. 2007. Compendium of Brassica Diseases. APS Press, St. Paul, MN, 117 pp.

Robak J. 1991. Zmienność patotypów Plasmodiophora brassicae Wor. występujących w Polsce i ich patogeniczność w stosunku do odmian i linii hodowlanych Brassica oleracea. Instytut Warzywnictwa w Skierniewicach. Praca habilitacyjna 6, 59 ss.

Somé A., Manzanares M.J., Laurens F., Baron F., Thomas G., Rouxel F. 1996. Variation for virulence on Brassica napus L. amongst Plasmodiophora brassicae collections from France and derived single-spore isolates. Plant Pathology 45: 432-439.

Wallenhammar A.C. 1996. Prevalence of Plasmodiophora brassicae in a spring oilseed rape growing area in central Sweden and factors influencing soil infestation levels. Plant Pathology 45: 710-719.

Wojciechowski A. 1993. Some morfological and phenological traits and fertility of lines of artificial winter oilseed rape originated from male-sterile plants (Brassica napus var. oleifera L.). Genetica Polonica 34 (4): 317-325. 